DEAN BAKER, CO-DIRECTOR, CENTER FOR ECONOMIC AND POLICY RESEARCH

KEVIN HASSETT, SENIOR FELLOW AND DIRECTOR OF ECONOMIC POLICY STUDIES, AEI

CO-SPONSORED WITH AARP

As the rhetoric of the election fades, America faces a dire fiscal cliff that will require honest discussion of entitlements. Must Social Security and Medicare be cut or can that be avoided through more revenue or other reforms? If benefits are reduced, how should that be done? Two prominent national experts -- Dean Baker and Kevin Hassett -- will discuss the options and momentous decisions facing Congress and the next President over the future of these two important federal programs. Baker and Hassett come to the debate as among the most thoughtful progressive and conservative commentators on entitlement reform.

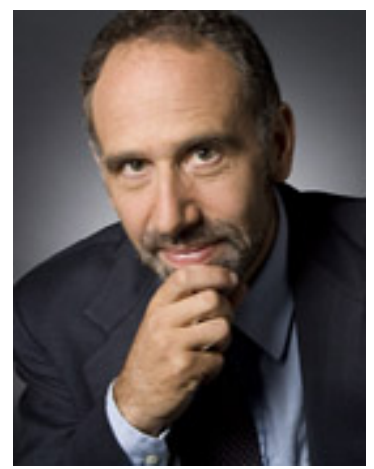

\title{
DEAN BAKER
}

Dean Baker is co-director of the Center for Economic and Policy Research in Washington, DC. He is frequently cited in economics reporting in major media outlets, including the New York Times, Washington Post, CNN, CNBC, and National Public Radio. He writes a weekly column for the Guardian Unlimited (UK), the Huffington Post, TruthOut, and his blog, Beat the Press, features commentary on economic reporting. His analyses have appeared in many major publications, including the Atlantic Monthly, the Washington Post, the London Financial Times, and the New York Daily News. He received his Ph.D. in economics from the University of Michigan. Dean has written several books, his latest being The End of Loser Liberalism: Making Markets Progressive. Dean previously worked as a senior economist at the Economic Policy Institute and an assistant professor at Bucknell University. He has also worked as a consultant for the World Bank, the Joint Economic Committee of the U.S. Congress, and the OECD's Trade Union Advisory Council. He was the author of the weekly online commentary on economic reporting, the Economic Reporting Review (ERR), from 1996 $-2006$.

\section{KEVIN HASSETT}

Kevin Hassett is a Senior Fellow and Director of Economic Policy Studies at the American Enterprise Institute (AEI). Before joining AEI, Mr. Hassett was a senior economist at the Board of Governors of the Federal Reserve System and an associate professor of economics and finance at the Graduate School of Business of Columbia University, as well as a policy 


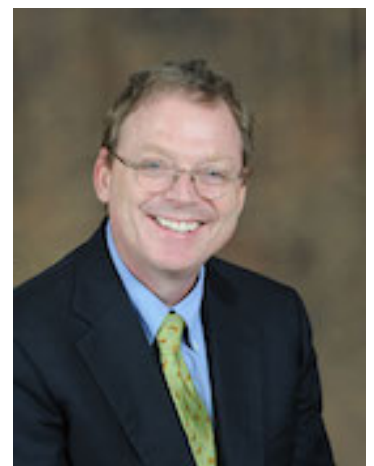

consultant to the Treasury Department during the George H. W. Bush and Clinton administrations. He served as an economic adviser to the George W. Bush 2004 presidential campaign and as Senator John McCain's chief economic adviser during the 2000 presidential primaries. He also served as a senior economic adviser to the McCain 2008 presidential campaign. Mr. Hassett is a columnist for National Review. Hassett received his Ph.D. in economics from the University of Pennsylvania. 